\title{
Using Movie Scenes as Conceptual Framing Exemplars to Guide School Leaders in Thinking Reflectively about Organizational Change
}

\author{
Joseph Claudet \\ Department of Educational Psychology and Leadership, Texas Tech University, Lubbock, TX, USA \\ Email: joe.claudet@ttu.edu
}

Received 14 November 2014; revised 5 December 2014; accepted 20 December 2014

Copyright (C) 2015 by author and Scientific Research Publishing Inc.

This work is licensed under the Creative Commons Attribution International License (CC BY). http://creativecommons.org/licenses/by/4.0/

(c) (i) Open Access

\begin{abstract}
This article describes the use of conceptual framing exemplars as an instructional tool to enhance the university graduate-level teaching and mentoring of education leaders (teachers, principals, instructional coaches, curriculum/special program directors, superintendents) interested in further developing their professional knowledge and skills in designing and implementing effective school improvement initiatives in elementary and secondary school settings. The article includes a discussion of selected organizational change leadership concepts that often pose learning challenges to school leadership graduate students, along with some specific examples of classic and popular movie scene conceptual framing exemplars that the author has employed in university graduate teaching seminars to assist leadership students in reflecting on the challenges and opportunities associated with enacting meaningful change leadership in schools. Some current, realworld school case situations are highlighted to illustrate how graduate students can apply reflective insights gleaned from their study of organizational change leadership conceptual framing exemplars to directly inform their own practical efforts in developing and implementing creative action strategies to improve teaching and learning effectiveness in their school communities.
\end{abstract}

\section{Keywords}

Organizational Change and Improvement, Conceptual Framing Exemplars, Collaborative School Leadership

\section{Introduction}

Ever since Auguste and Louis Lumière gave their first public screening at the Salon Indien du Grand Café in 
Paris in 1895 of a set of ten projected “moving picture” short films (each approximately 40 seconds in length)_ a set which included the very first short film they created entitled La Sortie de l'Usine Lumière à Lyon [literally: “The Exit from the Lumière Factory in Lyon", more commonly known by its English title: "Workers Leaving the Lumière Factory"] — to demonstrate their new cinématographe invention, a three-in-one device that could record, develop, and project moving pictures (Chardère, 1995), successive generations of videographic artists and cinematographers have sought to represent reality on the silver screen. Although there were a number of inventors at the time who were making technological contributions to the general development of cinematography, the Lumière brothers were among the very first pioneers who understood its considerable potential. While the Lumière brothers, who are often credited as among the first inventors of the specific "cinematographic technology" that enabled cinema as a mass medium, were doubtless aware of the practical societal importance of their breakthrough invention, perhaps even they may not have foreseen the varied and rich applications that their “moving pictures" technology would spawn in the coming century. Their technological inventiveness and the eventual worldwide moviemaking industry that grew from it in time both revolutionized existing societal practices and created a number of new professional areas, including video news production and network broadcasting. Their cinematographic technology has since been applied in almost every area of scientific inquiry. Their invention has also had a profound impact in the field of education. Today, of course, cinematographers leverage technological advances in the medium to continue the now century-old practice (and art) of telling stories with moving pictures on celluloid and, more recently, with digital pixels. In a social evolutionary sense, cinematic movies represent a logical continuation and technological expansion of the long history of dramatic theatre as a storytelling art form in human social consciousness. To be sure, a large part of the enduring appeal of traditional theatre, classic films, and popular movies is the fact that these are all, in essence, representational platforms for portraying human interaction in intriguing contexts and settings. And, the most compelling theatrical and cinematic portrayals are always those that succeed in uniquely dramatizing in memorable ways captivating human stories-and the challenging issues, multi-perspectivist conflicts, and human interactive encounters that fuel these intense dramatic situations.

For over two decades now I have been involved in teaching and mentoring university graduate students in the field of educational leadership. These educational leadership graduate students are most typically practicing elementary and secondary school educators (classroom teachers, school principals and assistant principals, curriculum directors, district central office program administrators, school district superintendents and associate superintendents) who, as an integral part of their professional advancement goals, elect to pursue masters and doctoral degrees along with accompanying professional certifications in campus- and district-level administrative leadership. Traditionally, elementary and secondary school educators embark on graduate study in educational leadership at various stages during their professional practice careers. Classroom teachers who are in the early stages of their school leadership careers and who have accumulated two or more years of teaching experience can elect to pursue school leadership masters degrees and certification endorsements to become campuslevel principals. Similarly, seasoned school administrators (campus principals, assistant principals, curriculum specialists, district program directors, etc.) at some point in their administrative careers may make the decision to pursue advanced doctoral study to prepare for the rigors of district-level executive administrative leadership.

Early on in my graduate teaching career, I began to think seriously — and pedagogically_about the task of how to go about teaching elementary and secondary school leaders about the challenges and pitfalls associated with assuming administrative roles as school- and district-level change agent leaders. I quickly realized that, given the entire constellation of interconnected concepts and ideas that exists surrounding the subject of organizational change leadership in people-intensive school leading and learning communities, students would need help in: 1) mentally making sense of and internalizing these complex concepts and ideas; and 2) learning how to apply insights related to and drawn from these concepts and ideas in practical ways in multiple, real-world school leadership contexts. These change leadership concepts and ideas can often seem very abstract and hard to grasp for students-particularly for students who are just embarking on their school leadership careers and who have not yet accumulated substantial leadership experience. Thus, as I continued to work with graduate students during my early years of graduate teaching, I became increasingly convinced that the fundamental pedagogical challenge associated with teaching graduate students about organizational change leadership involves helping students learn how to: first, navigate around and generate deep insights about the interrelated sets of concepts and ideas associated with the notion of change agent leadership; and then secondly, be able to directly apply these insights in the practical arena of schools and school districts. This practical application ability involves 
school leaders developing their skills in being able to effectively "leverage” their change leadership insights to design and implement creative action strategies that can bring together large numbers of diverse education stakeholders and motivate these stakeholders to work collaboratively to realize positive change and improvement in their school and school district communities.

The challenges involved in teaching about organizational leadership have naturally led me over the years to employ a broad multidisciplinary approach to helping students explore and think critically about difficult organizational behavior concepts. In particular, I have always been fascinated by the potential of dramatic theatre and cinema as pedagogical tools for portraying the subtleties of human interactive behavior and as a means for framing the unique kinds of organizational challenges these interactive behaviors can present to change agent leaders. Thus, as an integral part of my multidisciplinary teaching efforts over the past twenty-five years, I have continuously sought out compelling scenes from both historical and current theatrical and cinematic productions that could be utilized in meaningful ways as creative tools to inform my teaching about organizational leadership. An early encounter I had at the outset of my teaching career with one seminal theatrical production, in particular, proved to be a powerful stimulus steering me toward a long and fruitful decades-long journey focused on exploring the possibilities of dramatic theatre and cinema as creative teaching tools.

During the mid-1970s I attended a production of the 1965 Broadway musical stage play Man of La Mancha. The Man of La Mancha musical was based on a stage play "book" by Dale Wassermann, with lyrics written by Joe Darion and music composed by Mitch Leigh. Of course, the Man of La Mancha musical production itself was a long running "stage play adaptation" of the classic early seventeenth century social satire novel by Miguel de Cervantes Saavedra: Don Quixote de La Mancha (Cervantes Saavedra, 1605). Notably, Cervantes Saavedra’s novel presented a scathing portrayal of the church-dominated intellectual rigidity of the times and highlighted how this hierarchically imposed rigidity served to undermine any legitimate open quest for truth by inquiring scientific minds. There is an intriguing opening scene in Man of La Mancha that is portrayed with special effectiveness in the 1972 cinematic version of the musical. In this opening street scene set in the time of the Spanish Inquisition, Miguel de Cervantes, a poor playwright (played by Peter O’Toole) and his loyal assistant, Sancho Panza (played by James Coco) are engaged in leading their band of itinerant bardsmen in a morality play mocking the intellectual rigidity of the contemporary church authorities. Cervantes and his companion Sancho are quickly arrested and thrown into a dungeon, where they are forced to defend themselves against the taunts, jibes, and physical assaults of the dungeon's prisoners-a motley group of common miscreants, thieves, and murderers. To survive among these ruthless cutthroats, Cervantes (Peter O’Toole) cleverly deflects the prisoners' attacks by offering them the opportunity to take part in an "entertainment" - a fanciful play, which he creates for their amusement. Cervantes entices the prisoners to "hear him out" by inviting them to participate in a highly creative, collaborative endeavor: "With your permission, I will continue in the manner I know best, in the form of a charade-a play if you will. At worst it may beguile the time. And since my cast of characters is large, I call upon you all to enter in and play whatever role may suit your fancy... Well, if you have no objections, and with your kind permission, may I set the stage?” (Opening excerpt from the musical film, Man of La Mancha, 1972) With this exhortation, Cervantes proceeds to immerse these prisoners in a "play-within-a-play" about the exploits of a fictional, reclusive old gentleman named Alonso Quijana and his alter ego: the dauntless knight Don Quixote de la Mancha.

Cervantes "sets the stage" for his audience of prisoners (who essentially become his "students") to involve them directly in this immersive and collaborative "play-within-a-play virtual learning experience" to "teach" these prisoners-turned-actors about organizational change leadership - through following and participating in the exploits of the fictional Don Quixote as he jousts with organizational injustices and pursues the real meaning of "the impossible dream". As Cervantes explains to his fellow prisoners in defense of his "play-within-a-play charade" technique: "Reality [is] a stone prison crushing the human spirit. Poetry demands imagination, and with imagination one may discover a dream". What Cervantes means by this is that the "reality" of social organizations - with their complex problems, harsh injustices, and seemingly unending travails—can be numbing and burdensome, and can easily strain the human capacity (and will) of organization members for engaging in creative and meaningful (i.e., poetic) change agent leadership. Cervantes was, in fact, utilizing immersive teaching and learning techniques to dramatically portray for these prisoners (as well as for his readers and subsequent theatrical audiences) important social and political issues of the times, and how these collective "organizational challenges” highlighted the need for thoughtful (i.e., imaginative) change agent leadership “action”- grounded solidly in universal principles of truth and justice. 
Following Cervantes Saavedra's lead, I have found it useful throughout my teaching career to look for creative ways to similarly "set the stage” for students' learning. I have learned from Cervantes that the real instructional challenge is to find creative, immersive ways to capture students' interest and inspire their creative imaginations. In teaching about school change leadership this involves assisting students in developing their own critical thinking abilities in mentally relating to and internalizing difficult concepts and principles associated with organizational leadership and then creatively applying their hard-won insights directly to the realworld challenges associated with improving teaching and learning in schools. Just as Cervantes cleverly employed the "play-within-a-play" immersive teaching and learning technique to capture the interest of his audience of prisoners within his historical/dramaturgical context (as well as his larger theatrical audience in the stage play and cinematic adaptations of his book), I have sought in my own teaching to utilize this same "play-withina-play" immersion technique to capture the interest of graduate educational leadership students to assist these school leaders in engaging imaginatively in the process of exploring, constructing, and applying deep insights about complex organizational change leadership concepts to the real-world task of improving teaching and learning in schools. Thus, early on in my teaching career I adopted the strategy of employing carefully selected scenes from classic films and popular movies (as well as scenes from theatrical productions) as a way to provide accessible, contextually grounded conceptual framing exemplars that students could mentally identify with and use as starting points (i.e., “conceptual frames”) for critically thinking about complex organizational change leadership issues. In particular, I have found that these conceptual framing exemplars can be an effective instructional tool for engaging students in exploring creative solutions to the kinds of entrenched organizational change challenges that teaching and learning dilemma situations in elementary and secondary campuses can present to school leaders.

\section{Conceptual Framing Exemplars as an Instructional Tool}

The study of organizational change leadership involves investigating interrelated sets of complex concepts, principles, and variables that collectively help to inform our understanding of how people in leading and learning organizations — such as schools and school districts - interact with each other on an ongoing basis to find creative solutions to challenging problems and move their organizations forward. School leaders working with education stakeholders in today's elementary and secondary schools and districts are constantly grappling with the challenges associated with improving the quality of instructional planning and teaching in their school communities to address the diverse learning needs of their students. To tackle the intense teaching and learning challenges currently existing in many school district settings, school leaders and their educator colleagues must continuously engage in a variety of interrelated and ongoing school improvement activities, including: 1) identifying learning deficiencies in various student populations within and across multiple content areas as well as aspects of the overall school district instructional delivery system in need of improvement; 2) designing targeted improvement initiatives to address student learning deficiencies and need areas; and 3) working to systematically implement these learning improvement initiatives to enhance the school district's overall productivity and effectiveness. Because of the complexity and multi-leveled nature of organizational life in schools, the study of school organizational leadership - and, in particular, the study of how to enact positive change and improvement in school organizations - can quickly become a daunting task for even the most dedicated school leadership students. The complex concept of organizational change leadership, in fact, is positioned within a constellation of interrelated ideas, constructs, and sub-constructs that straddle multiple dimensions associated with the interactive processes and practices of leading and learning in individual schools and school districts. These multiple “dimensions" encompass several core elements of school district community life, including: sociopolitical context and educational culture, internal and external communication networks, strategic planning and decision making channels, systems performance oversight and accountability mechanisms, and the like (Munro, 2008; Owens, 2004). In recognition of this complexity, school leadership graduate students' understandings of the challenges involved in enacting meaningful change leadership in school organizations should grow and develop in an organic, integrated way within and through all of these interrelated organizational dimensions (in the same way that genuine insightful understandings about any complex idea grow organically inward and outward in all directions and are woven within and through the idea's multiple dimensions). To help students make sense of this complexity, the study of organizational change leadership in schools requires some solid "anchoring” in the realities of human interaction. 
Cinematic portrayals of human interactive conflict, resiliency, and change leadership in organizational settings, as can be found in classic films and popular movies as well as in dramatic theatre productions, offer an array of readily available and applicable resources that can be employed as creative "instructional tools" to assist school leadership students in engaging reflectively with the kinds of organizational challenges (roadblocks, obstacles, and constraints) that change agent leaders will often encounter in real-world school leadership situations. Indeed, movie scenes can "dramatically frame" for students these kinds of intense change agent challenges in ways that are especially vivid and memorable. Well-crafted, compelling movie scenes that portray intense, interactive situations and encounters have a way of becoming "mentally imprinted" in a multisensory way both visually and orally in viewers' minds. These movie scenes tend to stay with us and become part of our mental environment-we remember these scenes and, when we choose, we can "replay" these scenes over and over in our own minds. As such, movie scenes can become a kind of mind-stage laboratory theatre within which graduate students can mentally explore (turn around in their minds, take apart, and critically examine in detail) the complex challenges involved in enacting systemic change in multi-stakeholder organizations. Importantly, carefully selected movie scenes—scenes that highlight intense interactive encounters between/among characters involved in the contextual realities of organizational change in vivid story settings and places—can serve as powerful catalysts for engaging students in deep reflective dialogue about specific elements and dimensions of organizational change leadership. These organizational elements and dimensions reflect the multifaceted, vexing challenges that can arise when change agent leaders attempt to enact systemic change in organizational settings in which multiple stakeholders and stakeholder groups espouse passionate, conflicting perspectives, values, and beliefs regarding key issues of importance to the organization. Thus, carefully selected movie scenes can be used as conceptual framing exemplars to contextually ground and help clarify students' own critical reflective thinking about these complex organizational concepts and issues. The use of movie scene conceptual framing exemplars in graduate teaching seminars can spur students to explore and develop new insightful understandings in their own minds regarding the challenges involved in enacting effective change leadership in organizational situations in which stakeholders are embroiled in intense multi-perspectivist conflict over core issues of central importance to the organization. Moreover, these conceptual framing exemplars can help students reflectively examine and refine their practical leadership skills in applying their newly generated leadership insights to inform their efforts in designing and implementing creative school improvement action strategies in their own school leadership practice to address real-world teaching and learning challenges in meaningful ways. Intriguingly, utilizing movie scene conceptual framing exemplars as an instructional tool can also expand opportunities for graduate students to creatively explore new multidisciplinary connections in their leadership thinking as students begin to critically examine organizational change leadership situations and problems through multiple analytic lenses (e.g., social, cultural, economic, political).

Rather than seeking to present an exhaustive, comprehensive listing of movies and movie scenes that can be used as portrayals of organizational change leadership challenges, in this article I present a sampling of selected scenes from classic films and popular movies which I have studied intensively for their "leadership insight value" and have utilized as conceptual framing exemplars in my own school leadership graduate teaching. In the sections below I present an overview of these selected movie scenes and discuss how these scenes can serve as useful conceptual framing exemplars to stimulate students' reflective thinking about the challenges and opportunities associated with designing and implementing meaningful improvement initiatives to enhance teaching and learning effectiveness in schools.

\section{Discussion}

The sections below provide some specific examples of important organizational change leadership concepts that often pose challenges to school leadership graduate students, particularly in terms of students being able to: 1) develop and internalize change agent insightful understandings regarding these leadership concepts; and 2) apply these insightful understandings in their own school leadership professional practice to directly inform their strategic action plan development efforts in real-world school district settings. Following each "leadership concept", I provide the reader with a description of one or more selected movie scene conceptual framing exemplars identified from classic or recent popular movies that I have used in my graduate teaching to assist students in thinking "reflectively" and "in depth" about the identified leadership concept. I then contextualize these conceptual framing exemplars within current school leadership professional practice through discussing how each set of movie scene conceptual framing exemplars can be mentally applied to inform an analysis of a real-world 
school teaching, leading, and learning improvement "case in point" situation. This use of conceptual framing exemplars as a reflective application tool represents an instructional means to help students: 1) extend and deepen their insightful understandings regarding an identified leadership concept; and 2) directly apply their refined understandings about the leadership concept "in context" to illuminate and strengthen their organizational change leadership decision making practices in real-world school settings.

\subsection{Leadership Concept: Nurturing a "Collaborative Teaming Mindset" among Multiple Stakeholders to Support School District-Wide Instructional Change and Improvement}

One of the most persistent challenges confronting education leaders in many school districts today is that of building a collaborative teaming mindset among multiple stakeholders in the school district organization-a collective mindset that is capable of developing and supporting a shared team vision for how school leaders can best utilize the district's limited resources to effectively address the learning needs of all students. On the surface, developing a shared vision among multiple groups of education stakeholders (teachers, campus principals, parents, community business and civic leaders, district-level curriculum directors, instructional program coordinators, school board members) on how to effectively provide for the learning needs of all students in a school district community might appear to be a relatively straightforward endeavor. In principle, all education community members have an economic stake in providing for and supporting the learning needs of children attending their community's schools. And, because of this, one might think that all stakeholders presumably would be supportive of their school district's efforts to design and implement needed instructional programs to ensure that all students learn effectively. However, in practice, the task of nurturing a shared vision of school learning effectiveness is often much more difficult to accomplish, as education stakeholders (acting both individually and in stakeholder groups) frequently hold passionate beliefs and perspectives regarding how and in what specific ways individual campuses and the school district as a whole can and should accomplish the task of optimizing learning opportunities for all students. Individual stakeholders and stakeholder groups can and often do harbor intense, perspective-driven views on the merits of various instructional programs that a school district already has in place or may be considering for future implementation. In particular, as a dependable part of the organizational life of school districts, education community stakeholders can be relied upon to develop and voice their perceptions regarding a variety of issues associated with their school district's existing or proposed learning improvement programs attempting to address the learning improvement and support needs of any one or more "targeted' student population subgroups (e.g., low socioeconomic and disadvantaged learners, culturally marginalized learners, special needs learners). For example, education stakeholders may express strong doubts regarding the "achievability" of the improvement goals established by the district for one or more program initiatives. Additionally, stakeholders might voice their concerns regarding multiple implementation and sustainability "roadblocks" that they perceive could potentially emerge with various proposed school district learning improvement initiatives. And given today's high-stakes performance accountability climate wherein school districts are under constant pressure to achieve demonstrable learning improvement gains with limited resources, community stakeholders will predictably ask probing questions and demand clear justifications from district leaders regarding the overall "cost effectiveness" and "organizational worthiness" of individual learning improvement program initiatives. These multiple education stakeholder views-sometimes in direct conflict with each other-quickly develop a community-wide, "critical mass" momentum of their own and can frequently be found in stark display in heated interchanges at school district board meetings.

Many school districts across the United States are currently facing intense pressure to increase students' learning performance on state mandated tests in core content areas such as math and reading as a result of more rigorous state and national academic standards and heightened performance accountability demands. These increased standards and accountability demands come at a time when many school districts are being impacted by substantive demographic shifts in their overall state and regional populations. These demographic shifts are resulting in the emergence in many school districts of continually increasing percentages of Hispanic and other ethnic student populations as well as increasing numbers of low socioeconomic students in their overall district student enrollments. This growing diversification in the student and family population dynamics of school districts is, in many cases, dramatically redefining the overall landscape of instructional challenges and program demands for education leaders-particularly in terms of the ability of school district personnel to be able to respond adequately to the learning needs of these diverse students. School district education leaders (superinten- 
dents and assistant superintendents working closely with their central office staff of elementary and secondary curriculum directors and instructional program coordinators) are attempting to respond to this pressure in many instances by designing and implementing new multicultural curricula-along with new multiculturally sensitive instructional programs for these curricula-throughout their districts.

As a case in point: in one rural school district community in southwest Texas with a 43 percent (and growing) overall Hispanic student population as well as a disproportionately large percentage of low socioeconomic students (many of whom are Hispanic and/or other ethnic minority students), school administrators have initiated new district-wide curricula and instructional program initiatives to attempt to address the specific learning needs of these students. District central office curriculum directors, working collaboratively with some of the district's veteran teachers and with content area specialists from the neighboring regional education service center, worked conscientiously within multiple year-long "new curriculum development initiatives" to incorporate multiculturally sensitive reading texts and math word problems into the district's elementary and middle level English language arts (ELA) and math instruction and assessment materials. These efforts were undertaken specifically to make classroom instruction more responsive to the needs of the school district's large and continually growing populations of Hispanic, low socioeconomic, and marginalized students. Ironically, these curriculum and instructional development initiatives have generated substantial divisiveness among multiple community stakeholder groups over the perceived "merits" of the new programs. While these efforts to refine the district's curricula and instructional materials were received very favorably by many teachers in the district, notably by newer teachers to the district with ten or fewer years of teaching experience who were strongly aware from their university professional preparation of the benefits of a multicultural curriculum, the new programs were also met with some intense resistance from some of the district's veteran teachers. These veteran teachers objected to the substantial "additional work demands" that the new programs were placing on their teaching. The additional work included having to attend required "professional development trainings" on the new curriculum and instructional materials, which were an integral component of the superintendent's widely promoted Teaching and Learning Success for All Students district-wide instructional improvement initiative for the current school year. Parents in the community were also divided on the merits of the new curricula and instructional programs, with some parents siding with the veteran teachers while other parents were more generally supportive of the new programs. To complicate things further, some of the "supportive" parents were questioning whether the new programs were actually going far enough in meeting the multicultural learning needs of their children. These multiple, conflicting stakeholder beliefs and perspectives regarding the district's new instructional improvement initiative and associated programs quickly mushroomed into an intense and highly volatile "multi-perspectivist logjam" affecting the entire school district community. The conflict spilled over into monthly school board meetings, with school board members (who were themselves divided on the issue), parents, and district administrators engaging in heated debates over the merits of the superintendent's district-wide instructional improvement initiative. The intense controversy regarding the new instructional improvement initiative that erupted in this rural school district community ended up dividing community stakeholders over the important issue of how to provide quality teaching and learning opportunities for all of the district's increasingly diverse students. Moreover, this community-wide controversy put in jeopardy (at least for the foreseeable future) any real prospects for a successful implementation of the new district-wide program. The above rural school district community instance of multi-stakeholder conflict over how to go about meeting the challenges of providing effective instruction to an economically and culturally diverse student population is offered as one example of the kinds of multi-perspectivist stakeholder conflict that can emerge in school district communities today-communitywide conflict that can stymie the most well-intentioned instructional improvement efforts of school district leaders.

There are a number of possible movie scenes that can be used as conceptual framing exemplars to provide a reference point for teaching about the challenges associated with nurturing a community-wide "collaborative teaming mindset" among stakeholders in school organizations. Presented below is a discussion of one classic movie scene in particular that I have used as a conceptual framing exemplar to assist educational leadership graduate students in identifying and probing the multiple (and multi-level) challenges that change leaders can often encounter as they attempt to work with stakeholders to build positive leadership teams and a shared vision of organizational improvement. This classic movie scene is briefly described along with an analysis of how this scene can be employed as a "conceptual frame" or reference point to guide students in thinking reflectively about the concept of collaborative teaming-including how to develop creative strategies for nurturing effective collaborative teaming practices in their schools and districts. 
The Godfather

One famous movie scene which I have used frequently in my graduate teaching to illustrate to students the multiple challenges involved in nurturing a collaborative teaming mindset in school organizations is the well-known "Five Families Scene" from The Godfather movie (1972). This classic American movie is based on the bestselling book of the same title written by Mario Puzo (Puzo, "The Godfather", 1969). The movie was directed by Francis Ford Coppola and produced by Albert S. Ruddy, from a screenplay by Mario Puzo and Francis Ford Coppola. Francis Ford Coppola's 1972 movie and the larger cinematic "movie trilogy" that emerged from this initial movie-The Godfather (1972), The Godfather: Part II (1974), and The Godfather: Part III (1990)—portrays the saga of criminal racketeering, multiple family feuding, and empire building of the Italian mafia organization in America during the first half of the twentieth century. The initial installment in the movie trilogy, The Godfather (Coppola, 1972) movie, presents a storyline which vividly portrays this highly competitive, "multiple family feuding" environment. As portrayed in the movie, the mafia "dons" (the heads of the individual Italian mafia families) and the family-centered regional mafia groups they preside over conduct their family-centric racketeering operations based on an intense "regional protectionist" mentality (a mentality that has been a fundamental part of these Sicilian mafia families' way of life for centuries) — using threats and strongarm thug tactics to tightly control and protect at all costs their individual "regional" money-making interests. This "regional protectionist" mentality espoused by the various dons and their mafia groups, along with the dons' natural bent toward maximizing their profitability through turf expansion, provides the main ingredient for a highly unstable and volatile overall "mafia organizational environment". Competition between groups is intense and turf lines are frequently crossed, setting off episodes of vicious fighting and bloody retribution paybacks between groups-retribution attacks which sometimes result in individual dons' own sons being seriously wounded or killed. Such an event occurs in The Godfather (1972) movie storyline: one of Don Vito Corleone's sons is gunned down by thugs from a competing family mafia group (the Tattaglia family) in retribution for the killing of one of Don Tattaglia's sons. This series of disastrous events provides the immediate backdrop for the "Five Families" scene. In this famous scene, Don Corleone (played by Marlon Brando) has called a meeting of the five regional mafia families (the families controlling mafia operations in New York, New Jersey, the Bronx, Brooklyn, and Staten Island, as well as additional mafia associates from California, Kansas City, and other national territories) for the ostensible purpose of offering a "truce". During the meeting Don Corleone declares that he will forego engaging in any kind of personal vendetta and will not resort to further vengeance as a means to obtain retribution for his son's killing. As Corleone states to Tattaglia in the meeting: "Is vengeance gonna bring your son back to you? Or my boy to me? I forego the vengeance of my son". Rather, Don Corleone presents to the assembled dons his "rationale" for why he believes that the time has come for all the dons and their respective regional mafia families to begin working together to initiate a new era of broader organizational unity and common purpose based on mutual cooperation.

This scene is especially useful for framing the unique kinds of leadership challenges that can arise when attempting to nurture a collaborative teaming mindset among organization stakeholders. In this "Five Families" scene the assembled dons are essentially engaging in an elaborate pretense: they are all pretending to support Don Corleone's proffered gesture of peace and proposal for initiating a new chapter of mutual cooperation among the dons and their respective regional mafia groups, while in their own minds they are still very much committed to protecting their own (highly lucrative) regional turf interests. Historically, this "regional turf" mentality has been the overriding force guiding each don's individual mafia group leadership behavior, keeping the various dons and their regional mafia groups at cross-purposes and in vicious competition with each other. This strong desire on the part of the dons to protect their individual turf interests at all costs is fueled by their own core beliefs and their own understanding of the "payoffs" of organization membership as they see them. The dons essentially have a "regional turf payoffs" view of mafia organizational leadership-their only agenda is to continue to viciously protect their own regional turf, because they firmly believe that is the only way they can effectively ensure and maximize their own regional mafia group profits. The dons' narrow "regional turf mentality" and protectionist beliefs are forcing them and their individual mafia groups to engage in competitive behaviors-to choose competition over cooperation. In broader organizational behavior terms, the dons' competitive regional group "turf interest" infighting and acts of between-group retribution emanate from a decided preoccupation with their own self-interest driven opportunistic thinking. In working so single-mindedly to protect their own regional turf interests, the individual dons have been essentially working at "cross purposes" with each other, severely limiting — and, in fact, undermining — the broader national mafia organization's potential for 
lucrative cooperation and collaborative teaming. As an organizational leader, Don Corleone in this Five Families scene was attempting to help the assembled regional dons change and broaden their core beliefs about mafia leadership through embracing a new "radical idea". The radical idea that Corleone was proposing was that the dons would be able to realize much bigger and more lasting "payoffs" for both themselves and the collective, multiple families organizational group by adopting a broader, more interconnected "collaborative teaming mindset" - that is, by embracing a collaborative stewardship approach to "organization-wide" mafia teaming. The kind of collaborative stewardship approach to mafia organizational leadership that Don Corleone was proposing would reap much bigger payoffs for the multiple family groups acting together as a united national organization, and would enable the multiple families to end their long history of self-interest driven (and self-destructive) opportunistic infighting between family groups-which at that point in the movie had resulted in two of the dons' sons needlessly being murdered. Thus, the dons' interactive behaviors in this Five Families scene (along with the history of their respective regional mafia family groups' infighting behaviors up to this point in the movie) highlight issues of competition versus cooperation and how these group behaviors can differentially impact organizational effectiveness. Moreover, The Godfather (1972) Five Families scene serves as a means to frame and juxtapose the important broader organizational behavior concepts of organizational stewardship versus individual opportunism - and how these concepts (and associated stakeholder behaviors) emerge directly from stakeholders' own core organizational beliefs, which can influence stakeholders' attitudinal stance as participating organization members.

The Godfather (1972) movie "Five Families" scene can be used as an especially vivid conceptual framing exemplar to provide school leadership students with a starting-off point for engaging in reflective discussions about the kinds of creative leadership strategies that are necessary to help move groups of organization stakeholders from a self-interest driven opportunistic mentality to a collaborative stewardship mentality-the kind of organization member "mentality" or "mindset" necessary to support genuine and sustainable community-wide collaborative teaming. The Godfather (1972) Five Families scene, used as a conceptual frame to guide reflective analysis, can enable school leadership students to derive some important insights about the complex dynamics of multi-stakeholder interactive behavior in organizations and develop better understandings of how even the most well-intentioned change efforts can often end up being ineffective because of lack of adequate change agent follow-through. In particular, The Godfather (1972) Five Families scene can be used as a vivid movie scene conceptual frame exemplar for engaging school leadership students in focused discussions regarding two fundamental tenets of change agent leadership, namely: values redefinition and values integration. These two fundamental leadership tenets associated with the overall process of enacting meaningful change in leading and learning organizations highlight two important "character traits" possessed by effective change agent leaders: 1) a commitment to actively articulating one's own carefully considered values and beliefs regarding preferred organizational goals and group behaviors to others (no matter what the consequences) and, in so doing, redefining for organization members the values and beliefs that will be most conducive to the long-term health and prosperity of the organization; and 2) a dedication to working collaboratively with others to integrate - in an open and sustained manner - these values and beliefs directly into the organization's culture through proactive reform initiatives. In this regard, the best change agents of leading and learning organizations are those who, over the long-term, work conscientiously to dedicate themselves to developing and espousing these two leadership character traits of values redefining and values integrating. It is clear from subsequent scenes in The Godfather (1972) movie that Don Corleone did not "follow through" on his values redefining declaration statements to mafia organization members who had gathered for the Five Families conference meeting. Don Corleone did not connect his new "values redefining" statements with conscientious and sustained "values integration" efforts to insert these new values and beliefs solidly into the dons' organizational mafia culture. In essence, Corleone did not "walk his talk". Corleone fell short in this important dimension of change agent leadership by failing to work industriously over the long-term to help completely "reshape" the mafia organizational culture by substantively integrating his change agent "values redefining" ideas into the mafia dons' broader organizational culturemaking these new values part of the "core values" of mafia organizational life.

These two change agent leadership tenets (and associated character traits) of effective change agent leadership, namely, values redefinition and values integration - when presented and discussed in graduate teaching environments utilizing the "conceptual framing exemplar" instructional approach—can provide school leadership graduate students with useful insights to help students learn how to craft practical leadership action strategies to address the kinds of organizational change and improvement challenges educators and community stakeholders 
routinely face in their schools and districts. I have frequently used The Godfather (1972) Five Families scene highlighted above (often in conjunction with other selected scenes from The Godfather movie trilogy) as a compelling conceptual framing exemplar (a "setting the stage" starting-off point) for engaging school leadership graduate students in lively and probing analytic discussions regarding school stakeholders' multiple motivations and propensities in any given contextual situation (depending upon the real-world issues involved) for engaging in competitive versus cooperative behaviors and actions in schools and school districts. These discussions also include detailed explorations of how stakeholders' varied interactive behaviors in response to pressing organizational challenges - and the underlying stakeholder values and beliefs that fuel these behaviors - are so very often symptomatic of, and can often be classified as falling within, a larger dualistic "organizational mentality continuum". This organizational mentality continuum can be conceptualized as encompassing two polar opposites of possible stakeholder organizational "thinking" and "behavior": one end of the continuum represents stakeholder thinking and resulting individual and/or group behaviors and actions that reflect a decided bent toward self-interest driven opportunism (a "me-payoffs" mentality), while the other end of the continuum represents stakeholder thinking and resulting individual and/or group behaviors and actions that demonstrate a marked propensity toward selfless collaborative stewardship (a "team-payoffs" mentality). This kind of "dualistic continuum" construct can serve as a useful reference tool for helping leadership students develop analytic clarity and depth in their examinations of the motivations and underlying political and sociocultural root causes of school stakeholder behaviors, as well as help guide students in identifying appropriate "context-sensitive" sets of action strategies that have real potential for moving school communities forward in positive ways to address and overcome school stakeholders' educational challenges.

Referring again to the above mentioned rural school district "case in point" example: the veteran teachers in this rural school district organizational change example are displaying a "me-payoffs" mentality because they are only thinking narrowly about the pressures and extra work that the district superintendent's new multicultural curriculum and instructional demands are placing on teachers. That is, these veteran teachers' behaviors (as well as the similar behaviors of the school board and community members who support these veteran teachers' views) reflect a preoccupation with responding in a manner that is "in competition with" or "against" the new multicultural initiative. These educators and community stakeholders are espousing perspectives and enacting behaviors that are at cross-purposes with the district superintendent's new multicultural program initiative, effectively undermining this initiative. These stakeholders' educational values and beliefs are causing them to react, in the immediate short-term, in a competitive rather than a cooperative manner. They are not thinking about the broader, long-term "team payoffs" that could potentially be realized for all education stakeholders in the school district (teachers, parents, community members, and most importantly, current and future students) through implementing this multicultural curriculum and new multicultural way of teaching. Thus, a central challenge for school change leaders in this situation is to find creative ways to help these veteran teachers, parents, elected school board officials, and community members develop new insightful understandings concerning the broader, long-term (sustainable) "team payoffs" for the whole school district community that could be attained through embracing a "collaborative team mindset" to support school district-wide instructional change and improvement. Examples of the kinds of practical action strategies that change agent leaders could employ to help stakeholders develop these new understandings could include such activities as: 1) working to create multiple kinds of opportunities for school district educators and community members to engage in open conversations about the underlying "learning values" and multiple "teaching and learning payoffs" associated with the multicultural curriculum and instructional initiatives; and 2) proactively modeling these "learning values" and "teaching and learning payoffs" during change leaders' own ongoing professional practice interactions with school district educators and community stakeholders, as well as through active collaborative sharing of creative program implementation ideas and instructional best practices with teacher colleagues.

\subsection{Leadership Concept: Using Conflict Creatively as a Catalyst for Positive Organizational Change}

Burgeoning population growth, especially in the Hispanic population, is continuing to cause substantive population shifts in the demographic profiles of many communities throughout the United States-a demographic trend that is dramatically affecting large swaths of the southwestern region of the country in particular. This ongoing regional population shift is directly impacting and intensifying the challenges of teachers and administrators in 
school districts serving these areas—educators who must now address the teaching and learning needs of highly diverse student populations. Many of these students are English Language Learners (ELLs)-Mexican-American (Latino) students who are entering the American educational system with a rich Hispanic cultural heritage and whose primary and/or only language in their home/family environment is Spanish. Coming from this monolingual (i.e., Spanish-speaking) home environment and, in many cases, being supported by parents who are operating at or near poverty level, these students find themselves struggling to succeed in the most basic of ways (both instructionally and socially) in American classrooms and, as a result, quickly become marginalized in the American public education system. Moreover, these Latino students' own school-level educational marginalization is all-too-often reflective of a broader community-level economic and social marginalization experienced by their families. As a result, school districts attempting to serve these students and their families have the dual challenge of needing to develop and implement creative learning intervention and instructional support programs to meet the multiple "academic learning" needs of these marginalized students as well as address the "school involvement and connectedness" needs of these students' marginalized families (parents and siblings).

The challenges associated with this multi-leveled marginalization phenomenon impacting Latino students and their families and the schools that are struggling to serve them take on special vividness and urgency in border districts-school districts serving rural and urban southwest US communities near the United States-Mexico border. Consider one mid-sized Texas border community approximately thirty miles from the US-Mexico border as a case in point. In recent decades this community has experienced rapid economic expansion and population growth, with an influx of diverse people from different parts of the world due in large part to the availability of high-mobility job opportunities in multiple public and governmental sectors, including manufacturing and industry, Texas Department of Public Safety, US Air Force, and US Border Patrol. These job opportunities have been steadily expanding in this region since the 1950s and 1960s, and have been further propelled in recent years by the United States-Mexico Free Trade Agreement (FTA). A large percentage of the families that have relocated to this region over the past several decades to fill these jobs are of Anglo (English-speaking) cultural descent, with an increase in recent years of newly-arriving families representing other cultures (Asian, French Canadian, German) as well. This regional manufacturing and government spawned economic growth continues to play out in tandem with the ongoing and ever-growing influx of Mexican-American (Latino) families into the community and region, many of whom are living at or near the poverty level. Latinos, in fact, now comprise the majority population (over 65 percent of the overall population) of this mid-sized city. One consolidated independent school district-consisting of seven elementary campuses (including a Head Start campus), two $6^{\text {th }}$ through $8^{\text {th }}$ grade middle schools, and one large $9^{\text {th }}$ through $12^{\text {th }}$ grade high school—serves the instructional and family support needs of this city school district's highly diverse, multiethnic student population. The school district's administrative leaders (superintendent, assistant superintendent, and curriculum and instructional program directors) have long recognized that serving the needs of this diverse student population base-particularly the intensive instructional and family support needs of the district's large Latino student population, many of whom are disadvantaged and marginalized learners-is a responsibility of all educators in the district. However, in practice, much of the practical work associated with providing instructional and school-home liaison support to Latino students and their families is handled disproportionately by the district's English teachers alone, particularly those English teachers who are bilingual and who teach classes for English language learners.

For example, the three bilingual English teachers at this border district's high school campus have been shouldering the bulk of the work of communicating on a regular basis with the parents of the high school's Latino students. Teachers in other core content areas (math, science, social studies)—many of whom are veteran Anglo teachers who have been teaching in the district for many years-are overwhelmed with their own departmental instructional demands and do not feel that it is their responsibility to have to communicate with these Spanish-speaking Latino parents. Indeed, many of the Anglo teachers are not bilingual—so, in these teachers' minds having to communicate with these Latino parents is an unwanted and burdensome challenge. This places considerable pressure on the high school's English teachers, who are tasked with meeting with Latino parents to discuss areas of concern regarding the English language arts and overall language literacy progress of their children in addition to having to try to respond to these parents' questions about their children's academic performance in other content areas such as math and science. This asymmetric progress monitoring, learning support, and school-home liaison communication "workload” that English and English Language Learner (ELL) teachers at this border district high school must shoulder is a phenomenon that is repeated across the entire district, as 
English and ELL teachers at the two middle schools are also engaged in similar kinds of extraordinary efforts in attempting to regularly communicate with and respond to the intensive instructional intervention/remediation and school-home support needs of Latino students and their families. Notably, many Latino parents are feeling that their own children are not being served well by the school district, and are voicing their own views that the kinds and quality of the instructional programs being offered at individual campuses in the district appear to favor Anglo students (along with benefiting the growing numbers of Asian, French Canadian, and German students) and are not directly addressing the unique multicultural learning needs of Latino learners. Moreover, this conflictive, multiple stakeholder "multicultural perspectivist environment" existing within the school district is reflective of a similar kind of "multicultural environmental conflict" playing out more broadly throughout this border community: the entire community’s organizational identity is in a state of flux, with different stakeholder groups expressing their own views regarding cultural identity and educational program effectiveness issues. Work-related stress and anxiety levels among teachers (in all content areas) across the entire district have continued to rise as a result of ongoing pressure from district administrators for campuses to demonstrate improved learning performance across all student population groups in response to state accountability demands. Fueling this volatility even further, community members (community business leaders, school board members, cultural support groups) - all harboring their own passionate views regarding the kinds of instructional programs they believe are needed for the district's students, as well as specific ways they believe educators and community members can and should be working together to meet these student needs-have entered into a community-wide debate regarding how to go about addressing the substantial student diversity-related teaching and learning challenges facing the district. These community members have aligned their own perspectives with various district educators' divergent views, siding with individual educator groups and administrators who are espousing substantively different educational solutions. Various conflicting stakeholder perspectives regarding how and to what extent the district should commit its limited resources to address the district's instructional effectiveness and school community support challenges have caused this debate to expand throughout the community, with explosive encounters between teachers and board members and between parents and school district administrators occurring with increasing frequency at campus sponsored parent-teacher events and school board meetings. This city school district, in short, is experiencing a perfect storm of challenging economic, sociocultural, and educational issues that have converged to create a school district community-wide organizational identity and instructional change leadership crisis.

In an intriguing sense, this unordered and continuously evolving convergence of multiple stakeholder cultural identities and conflicting educational values and perspectives in this border community setting contains all of the necessary ingredients required for deep organizational learning. However, this community has been languishing in this unstable environment of multi-perspectivist turmoil for some time now and is quickly approaching an organizational tipping point. The clash of cultural identities and competing educational values occurring in this border community along with the multiple stakeholder group interactive tensions that have been fomenting for several years have now converged into a full-blown organizational change leadership crisis for this school district educational community. What this situation desperately needs is the clear breakthrough leadership thinking and decisive moral leadership action of a seasoned change agent leader - a leader who is able to pull together a critical mass of school district community stakeholders and immerse these stakeholders in intensive, community-wide dialogue about their community's current educational challenges and the kind of future they want to build for themselves and their children. An experienced and committed change agent leader will understand that these communal dialogue encounters can serve as an important organizational learning crucible within and through which these multiple stakeholders - bound together by their situational proximity and their collective need to find a communal way forward — will be able to forge (out of their conflicting stakeholder perspectives) a common, shared educational vision of the school district community's most desirable educational goals and future direction. The change agent leader's challenge is to provide the galvanizing "organizational learning environment" along with the proper "moral leadership conviction and support" that, in combination, can serve as a transformative arena within which these multiple stakeholder groups can examine and reconcile their passionately held diverse perspectives into a unified vision—as an educational community —of who they are (and who they are continuing to become) and where they want to be going in their future.

In the section below I present a description and discussion of multiple scenes from one recent popular movie which I have used in combination as a conceptual framing exemplar set to engage graduate leadership students in reflecting on the creative ways in which one extraordinary leader was able to utilize intense multi-stakeholder 
conflict as a catalyst for enacting positive organizational change.

\section{Lincoln}

The Lincoln (2012) movie is an epic historical drama film that portrays the final four months of the Lincoln presidency. The movie vividly recounts Abraham Lincoln's decisive leadership efforts in January 1865 in securing the successful passage in the United States House of Representatives of the Thirteenth Amendment to the US Constitution to abolish slavery in all the states of the union and its territories. The Lincoln (2012) movie screenplay was written by Tony Kushner, and was based on the best-selling book Team of Rivals (2005) by Pulitzer Prize-winning author and historian Doris Kearns Goodwin (Goodwin, 2005). Lincoln (2012) was directed by Steven Spielberg (Spielberg, 2012) and co-produced by Spielberg and Kathleen Kennedy, with production company development support provided by DreamWorks Pictures and Participant Media. The Lincoln (2012) movie was released theatrically in the United States by Touchstone Pictures, and distributed internationally by $20^{\text {th }}$ Century Fox.

There are multiple scenes in the Lincoln (2012) movie that highlight Lincoln's interactive style and his political acuity—notably, his uncanny abilities in being able to clearly read the political thinking and strategic motives of the people (law makers and political operatives) surrounding him. Most intriguingly, these scenes also provide revealing glimpses into Lincoln's own breakthrough leadership thinking and moral leadership decision making. Lincoln's keen political "coalition building" insights are evident in an early scene in the movie in which Lincoln (played by Daniel Day-Lewis) visits the home of Francis Preston Blair (played by Hal Holbrook), one of the primary architects and founders of the new Republican Party, of which Lincoln is a member. Blair is a prominent elder statesman and a seasoned politician who is held in high regard by the conservative wing of the Republican Party. Serving as the staunch and resolute face of conservative Republican Party leadership thinking, Blair is passionately committed to working to find a peaceful, negotiated solution to the country's hostilities. Blair is sympathetic to Lincoln's insistency on proactively pursuing the Republican agenda to put an end to slavery forever through a constitutional amendment, but fears that realizing this worthy goal too quickly could just further inflame the already intense north-south fighting and perhaps irreparably divide the country. Blair's ardent desires for achieving peace first and only then proceeding to end slavery through constitutional amendment are in direct contrast with Lincoln's own strategizing views, as well as the views of influential congressional legislators comprising the radical wing of the Republican Party-legislators whom Lincoln was actively courting for their ardent support of Lincoln's push for immediate passage of the Thirteenth Amendment. Lincoln is well aware that radical wing Republicans in the US House of Representatives are adamantly opposed to any kind of north-south negotiated peace that would include a provision for the continuation of slavery within the union, and thus would oppose any efforts to engage in premature peace negotiations. While respectfully acknowledging Blair's urgent desires for ending hostilities and achieving peace, Lincoln is able to bring to bear his own more expansive and insightful breakthrough leadership thinking to clearly envision the optimal-and singularly workable-political strategy for securing the country's tenuous future. Given the politically fragmented national environment, Lincoln realizes that the only way to ensure full passage of the proposed Thirteenth Amendment in the intensely politically divided United States House of Representatives-and, thus, to secure a constitutionally sanctioned end to the moral scourge of slavery forever in the fragile American union-is to do so while the country is still immersed in the crucible of war. In Lincoln's mind abolishing slavery and restoring the American union were ultimately what the war was all about. Thus, the war itself must become the present enabling means through which passage of the Thirteenth Amendment is achieved. In this scene, Lincoln - the great political compromiser and coalition builder-is able to creatively broker a political understanding with Blair grounded in mutually shared first principles (as both men fervently desired north-south reunification and national peace). Lincoln agrees to Blair's demands to be allowed to go to Richmond, Virginia to attempt to arbitrate a negotiated peace in return for Blair's influential conservative wing Republican Party elder statesman support for Lincoln's push to move forward with passage of the Thirteenth Amendment in the US Congress. Lincoln's keen "political savviness" and "practical ingenuity" are on full display in this scene as Lincoln leverages his own considerable political conciliatory skills to secure the political support of a strong-willed and influential elder statesman to work together in pursuit of a shared vision of peace and unity for the country.

As the political maneuvering of key players in the national drama continues to unfold, there are two crucial scenes that appear later on within the movie that showcase in dramatic fashion Lincoln's own breakthrough leadership thinking processes and his unflagging, iron-willed determination to leverage these breakthrough in- 
sights to operationalize his moral convictions through forceful leadership action. The first of these two scenes presents Lincoln late in the evening, seated with his two administrative secretaries in a White House office, drafting a telegram to his union army commander, Lieutenant General Ulysses S. Grant. Lincoln becomes engaged in an impromptu conversation with his two young assistants about each individual's place in history and inquires of them if they think each person might be "fitted to the times we're born into". One of the assistants responds by stating that he is an "engineer" by profession: "I'm an engineer. I reckon there's machinery but no one's done the fitting". This statement prompts Lincoln to reflect on a principle of Euclidean geometry which he remembered reading as a young man: "I never had much of schooling, but I read Euclid, in an old book I borrowed. Euclid's first common notion is this: 'Things which are equal to the same thing are equal to each other'”. His two young assistants are not able to follow Lincoln's application of Euclid's principle to the present situation and stare uncomprehendingly at Lincoln. Lincoln then explains the "connection" of Euclid's principle to his own moral leadership thinking: "That's a rule of mathematical reasoning. It's true because it works; has done and always will do. In his book, Euclid says this is 'self-evident'. D'you see? There it is, even in that two-thousand-year-old book of mechanical law; it is a self-evident truth that things which are equal to the same thing are equal to each other. We begin with equality. That's the origin, isn't it? That balance-that's fairness, that's justice" (Kushner, 2012: pp. 98-99).

In a follow-up scene shortly thereafter in the movie, Lincoln directly applies this reflective thinking about equality and justice to the practical task of moral leadership decision making in a heated confrontation with his cabinet. Lincoln is engaged in a late night meeting with members of his executive cabinet and a few republican congressional leaders. The republican congressmen chastise Lincoln on his creative action strategies in pursuit of ensuring a quick vote in the House of Representatives on the proposed Thirteenth Amendment to the US Constitution that would abolish slavery now and forever. While these congressmen, mired as they are in their own rather narrow-visioned understanding of congressional politics, continue to argue incessantly about the considerable risks to their party of attempting to move forward with this audacious amendment passage plan, Lincoln's moral leadership insight rises above their banter. In this scene Lincoln's well-honed sense of moral purpose (developed and refined over an entire lifetime of observation and reflection on the human condition of the unfortunate masses of people around him) and his passionate determination to act on that moral sense come through with great vividness. In a pivotal moment in the scene, Lincoln forcefully interrupts the congressional members" bickering and demands that he and his republican political colleagues work purposefully to "seize the moment" - a moment which is presenting itself now as a result of a unique confluence of events, and that will not come again -and take action now: "I can't listen to this anymore! I can't accomplish a goddamned thing of any human 'meaning or worth' until we cure ourselves of slavery and end this pestilential war, and whether any of you or anyone else knows it, 'I' know I need 'this'! This amendment is that cure! We're stepped out upon the world's stage now, 'now', with the fate of human dignity in our hands! Blood's been spilt to afford us this moment!" Pointing demandingly around the table at each of the republican congressional leaders seated before him, Lincoln exhorts these legislators to take action: "Now, now, now! And you grousle and heckle and dodge about like pettifogging Tammany Hall hucksters! See what is before you! See the here and now! That's the hardest thing, the only thing that accounts!” (Kushner, 2012: pp. 127-128).

These two crucial scenes in the Lincoln (2012) movie, when paired together to highlight the "link" or "connectedness" between Lincoln's reflective thinking and his moral leadership action, provide outstanding conceptual framing opportunities for teaching about organizational change leadership. These scenes, when presented as a group within the larger context of other "coalition building" scenes occurring earlier in the movie (such as the Lincoln/Blair scene briefly described above), offer an especially compelling dramatic frame within which to instructionally "set the stage" for school leadership graduate students' own reflective thinking about organizational change leadership. In particular, these scenes provide a dramatic, historical backdrop against which students can engage in critical examination of the breakthrough leadership thinking and moral decision making processes of an exceptional change agent leader responding to the extraordinary organizational leadership challenges of his time. Lincoln was a self-educated man, the last in the line of "log cabin presidents" in American history. Despite Lincoln's lack of access to any formal education, he was highly inquisitive and continuously sought out and devoured books on many subjects. Lincoln was a voracious reader throughout his life, and this wide reading —and, in particular, his own thoughtful reflections on what he read—directly informed his leadership thinking. The late night scene in the movie involving Lincoln and his two administrative assistants (briefly described above), in which Lincoln quotes Euclid's common notion of mathematical equality and applies this 
idea to help elucidate the human justice challenges of his own time and context, demonstrates Lincoln's remarkable mental abilities in deciphering and internalizing essential truths from what he read, and then leveraging these truths wherever possible to arrive at compelling leadership solutions to the sociopolitical challenges before him. And, while Lincoln's breakthrough leadership thinking was grounded solidly in his careful application of fundamental truths to situational injustices, Lincoln —always the astute political pragmatist-also excelled at practicing the relational aspects of leading change. Lincoln understood the practical value of nurturing relationships and building coalitions, and was keenly aware of the importance of using time and circumstances to his advantage. Indeed, Lincoln at one point in the movie comments to his Secretary of State William Seward: "time is a great thickener of things". Lincoln's practical sociopolitical sensibilities and his ability to clearly read other people's political motivations and beliefs enabled him to display steadfast tact and patience (as well as genuine compassion) as he worked with multiple rival political party factions, helping congressional leaders over time develop and refine their own organizational thinking on difficult issues. Within the context of this constant encouragement and support, Lincoln also acted resolutely and insistently toward achieving his organizational goals and, in doing so, became a strong moral force for equity and justice, inspiring congressional leaders to find new ways to work together to forge consensus on critical issues and build a shared vision of national purpose and direction.

The selected scenes of the Lincoln (2012) movie described above (along with additional, relevant scenes dispersed throughout the length of the movie) can serve as a compelling set of conceptual framing exemplarsconceptual starting-off points-for engaging school leadership graduate students in focused reflection and dialogue about the intriguing change leadership challenges involved in navigating through and orchestrating collaborative solutions to intense organizational conflict. Importantly, these scenes can provide leadership students with a conceptual frame for examining the transformative potential of conflict in organizations and the ways in which creative change agent leaders are able to ingeniously co-opt and refashion conflict to serve their organizational purposes. This ability of highly expert change agent leaders (such as Abraham Lincoln) to use intense, multi-stakeholder conflict as a catalyst for positive organizational change centers on the change agent's focused leadership insights and skill in being able to: first, accurately assess the "transformative energy potential" embedded in multi-perspectivist conflict; and then, secondly, creatively leverage and redirect this conflictive organizational energy into a synergized catalyst for positive organizational change and improvement. Through critically reflecting on the clear breakthrough leadership thinking and decisive moral decision making actions of Abraham Lincoln, graduate leadership students can begin to examine and internalize important change leadership insights and explore opportunities for creatively applying these insights in real-world school district community settings. Importantly, through engaging with the Lincoln (2012) movie scene conceptual framing exemplars in tandem with carefully examining the "south Texas border school district" case example described above, graduate leadership students can discover parallels between the national "organizational identity and sociopolitical change" dilemma challenges faced by Lincoln and his $19^{\text {th }}$ century contemporaries and the school district community-wide "organizational identity and instructional change leadership" crisis being experienced by multiple stakeholders and stakeholder groups in this $21^{\text {st }}$ century south Texas border district community. Students can then use the organizational parallels they identify as a comparative framework for considering the possibilities of applying Lincoln-style breakthrough leadership thinking and relational coalition building to devise creative sets of sensible instructional improvement and family support action strategies that can move this border school district community forward in positive and inclusive ways. Most critically, leadership students will realize that the action plans they create must both challenge and empower school community stakeholders in this south Texas border community situation (educators, students, parents, and community members) to find new ways to work together with patience, tact, and compassion to forge consensus on critical issues and build a shared vision of border district community purpose and direction. In short, leadership students will glean new insights on how to use conflict creatively as a catalyst for positive organizational change.

\subsection{Leadership Concept: Leveraging 21 ${ }^{\text {st }}$ Century Technologies to Create Flourishing e-Learning Networks in Schools to Benefit All Learners}

Today's students are growing up in a digital world, a world that in many important respects is fundamentally different from the world of their parents and grandparents. The young people who are the students in today's elementary, middle, and secondary school classrooms have at their disposal new kinds of interactive digital tools 
(laptop computers, tablets, personal cell phones, and the like) that they use regularly to access information about their environment and the larger world around them and to communicate socially with their peers. These interactive digital communication tools are the natural birthright of $21^{\text {st }}$ century learners. Young people today communicate and learn naturally through frequenting Youtube and MySpace and a variety of other internet-accessible social sharing sites, and regularly interact digitally with their friends via instant messaging on Facebook. Students in elementary and secondary schools today, no matter what their socioeconomic level or ethnicity, are all familiar with "texting" and "surfing the internet" (worldwide web). Participating easily and continuously in these online social communicative activities is a vital and natural part of young people's digital interactive skill sets. And although within the past two decades many school districts have engaged in substantial efforts (and have expended considerable fiscal resources) to "equip" their schools and classrooms with computer technology and related classroom technologies (computer labs, classroom data projectors, smart boards, etc.) in an attempt to technologically revitalize the educational process for both students and teachers, unfortunately many of these well-intentioned efforts, to a significant degree, have failed. Many educators are now realizing that these "technology equipping” efforts have mostly failed because implementing “technology add-on” initiatives (the frequently top-down school district actions that involve putting computer technology into classrooms) are essentially surface-structural attempts at instructional change. Much of the "technology" that presently exists in many elementary and secondary classrooms, in fact, appears outmoded to today's digitally savvy students. School districts have implemented these surface-structural technology add-on initiatives while ignoring to a large degree the complementary (and critical) challenge of tackling the kinds of time- and effort-intensive deep-structural changes that must also be implemented if genuine instructional change is to occur. And this kind of deep-structural instructional change, if undertaken, will require education leaders (school district administrators, curriculum directors, technology support specialists, and campus-level teachers and principals) to engage together in no less than a comprehensive rethinking of the fundamental processes of teaching and learning-a collaborative, critical reflective effort that will necessarily involve school district and campus educators in: first, expanding and deepening their own core beliefs about teaching and learning; and then secondly, using these new, refined core beliefs as the basis for systematically reculturing the overall instructional environments of their school communities.

Consider the following example of the instructional technology integration challenges of educators and school stakeholders at one urban high school as a case in point. In a large urban high school situated in the Dallas/Fort Worth metroplex area in central east Texas, teachers and administrators of this sprawling campus of 3200 students are confronted on a daily basis with the time- and effort-intensive instructional planning challenges associated with integrating digital technologies effectively into classroom teaching and learning. As a result of state accountability demands for school districts throughout the state to demonstrate high levels of student learning performance in their elementary, middle, and high school campuses, educators at this Dallas/Fort Worth urban high school are under intense pressure to reach their district's identified student learning performance "improvement goals” within all major secondary content areas (English language arts [ELA], mathematics, science, and social studies). In addition, educators at this high school campus are also expected to provide enhanced "career readiness” instruction to secondary level students, particularly in math and science, to prepare students for possible future careers in STEM-related (i.e., science, technology, engineering, and mathematics) professional fields. Student performance data (consisting of student test results on state core content area assessments) are reported on annual campus- and district-level academic performance reports, and include an overall accountability index percentage score for individual campuses on the postsecondary readiness performance level of their secondary students. This postsecondary readiness percentage score reflects the extent to which students have acquired the academic foundation necessary for success in college, the workforce, job training programs, or the military. Individual school performance data are used to assign accountability ratings for each school in the district based on student performance "target percentage ratings" on accountability indices that are set by the state. This Dallas/Fort Worth area high school campus received a postsecondary readiness accountability index rating of 60 percent (15 percentage points below the state "target" percentage rating of 75 percent) —a "below expectations” rating that was documented on this high school's campus-level academic performance report for the most recent completed school year. Campus administrators (the principal and four assistant principals) at this urban high school are well aware that the school's inability to reach the state's target rating on the postsecondary readiness index to a large extent is due to the ongoing challenges these school leaders have been facing in getting their teachers to work collaboratively to creatively integrate available digital technologies into their grade-level in- 
structional practices. For these school leaders the practical task of motivating and supporting teachers in their weekly instructional teaming efforts to effectively integrate digital technologies (mobile devices and social media sharing and learning tools) into their classroom- and grade-level teaching has proven to be a daunting challenge.

To be able to uncover the root causes of this school's instructional technology integration dilemma, it is necessary to examine teacher practices at this school within and across multiple dimensions, including: 1) individual teachers' knowledge of digital technologies; 2) teachers' application skill levels in planning for and teaching with digital technologies; and 3) educators' teaching and learning core beliefs. Although many of the newer teachers on the faculty at this high school (teachers who have fairly recently completed their university professional teacher preparation/training and are in their first five to seven years of full-time teaching) are very familiar with digital technology tools and are highly enthusiastic about the potential of leveraging available digital tools to enhance classroom instruction, these "next generation" teachers are also serving on grade-level instructional planning teams with other "veteran" teachers, many of whom have been teaching for ten or more years (either at this high school or at other secondary schools, both in this district and in other districts). The school's "next generation" teachers are quite familiar with using mobile technologies (laptop computers, digital tablets, and the like) and social media (Youtube, Facebook, Twitter, LinkedIn, MySpace, Pinterest, Second Life, and similar internet sharing and networking sites) as creative digital tools to enrich lesson content and heighten students' learning interests. Adept at using these digital tools themselves, these "next generation" teachers understand well the value of leveraging these available digital tools to expand and deepen their students' $21^{\text {st }}$ century learning opportunities. As a result, these "next generation" teachers have completely internalized the instructional payoffs of teaching with digital tools - these payoffs are part of these teachers' core beliefs about effective teaching and learning. And although during grade-level instructional team meetings at this school many of the school's "veteran" teachers can frequently be seen nodding their heads in agreement while listening to their younger colleagues as these "next generation" teachers enthusiastically champion integrating these digital learning tools into their team's instructional unit planning efforts, these veteran teachers often end up stalling or even sabotaging some of the team's planned technology integration efforts. These veteran teachers' relative unfamiliarity with digital learning tools coupled with a general lack of available "hands-on" staff development offerings for teachers in the district on how to go about integrating mobile technologies and social media into teachers' instructional practices have combined to significantly raise these veteran teachers' anxiety levels regarding using digital technologies in their classrooms. Collectively, these veteran teachers to a large extent have shied away from using these digital learning tools in their own teaching and, thus, have been unable to experience (and internalize in their own minds) any positive instructional payoffs associated with the application and use of digital learning tools in their classrooms. As a result, these veteran educators' core teacher beliefs about effective teaching and learning have continued to be more traditional and technology averse in nature. The upshot of all of this is that many grade-level teacher teams at this urban high school have remained stymied in their digital learning and teaming efforts and have been unsuccessful as collaborative teacher teams in designing and implementing truly effective multidisciplinary and technology-integrated instructional units that can creatively expand and deepen students' learning.

This combination of lack of technology familiarity, unavailability of relevant and useful technology integration staff development, and resulting high teacher stress levels has caused many teachers at this urban high school to react negatively to the district's continuing calls for teachers to proactively integrate digital technologies into their instructional practices. Without appropriate district-wide technology training and support—and especially without comprehensive professional staff development being made available to teacher teams on how to collaboratively plan and teach with $21^{\text {st }}$ century digital learning tools (including helping teachers experience and understand the instructional payoffs of digital technology integration) - this school will continue to fall short in the provision of $21^{\text {st }}$ century learning opportunities to students.

In the section below I discuss one recent popular movie that I have used as an especially intriguing and relevant conceptual framing exemplar to help guide students in their reflections on the potential of connecting ideas about communal networks and collaborative learning with available digital communication and sharing technologies as a creative means for transforming teaching and learning opportunities for $21^{\text {st }}$ century learners.

\section{Avatar}

James Cameron's Avatar movie (Cameron, 2009) is undoubtedly one of the most creative science fiction films appearing in recent years. Advanced computer generated (CG) effects were employed to digitally create and 
render substantial segments of this movie. Notably, cutting-edge breakthroughs in the development and use of new stereoscopic cinematic technologies (specially designed for this movie) in conjunction with available "advanced motion capture" video techniques were utilized to enable and support production of the movie. The film's futuristic storyline takes place in the mid- $22^{\text {nd }}$ century and involves the intergalactic expeditionary efforts of humans who are interested in mining the rich deposits of "unobtanium" (a rare mineral and high-temperature superconductor used to fuel the $22^{\text {nd }}$ century human economy) that are found in abundance on Pandora, one of several moons orbiting a planetary gas giant in the Alpha Centauri star system. The planetary moon Pandora is home to hundreds of disparate Na'vi clans of ten-foot tall, blue-skinned indigenous humanoids-including the Na'vi "Omaticaya clan" who play a central role in the movie-all of whom share a deep cultural respect for all life forms inhabiting the rich, tropical Pandoran environment, along with a strong sense of interconnectedness with their environment. Na'vi clan members' respect for their natural environment and all life forms associated with this environment is reflected in their communal culture and artisanal practices in which Na'vi clan members celebrate the interconnectedness of nature through their tribal stories, songs, dance, and handcrafts. The Na'vi view their lush, tropical environment as a living, responsive "communication and learning network" that connects the Na'vi to each other, as well as to the wealth of knowledge possessed by their tribal ancestors. Intriguingly, the Na'vi understand the power of communal learning networks: the Na'vi clansmen intuitively understand and value the "interconnectedness" between and among all living things on their Pandoran moon, and they are highly adept at leveraging the natural environment and the interactive resources their environment has to offer (i.e., their environment's "interactive technologies") to expand and deepen their knowledge sharing and communal learning potential.

As a result of their physiological makeup the Na'vi can establish direct empathic communication links with other Pandoran life forms through a process of "queuing”. The Na'vi can connect physically via a system of neural tendrils (a "queue" sheathed in a long hair braid) to the neural tendrils ("queues") of other Pandoran life forms such as, most notably, the direhorse and the mountain banshee (other fanciful creatures inhabiting this fictional interstellar lunar environment). As explained by Wilhelm and Mathison (2009): "This neural connection allows a Na'vi to sense the energetic and kinetic signals broadcast by creatures, plants, and even the moon [Pandora] itself. It is believed that the queue also allows the Na'vi to access the neural network that envelops the entire [Pandoran] moon, and thus the collective wisdom of all Pandoran life. It is difficult to overstate the importance of the queue to the spiritual and physical well-being of the Na'vi” (Wilhelm \& Mathison, 2009: pp. 28-29). Interestingly, this kind of "plugged in" connectedness is a notion that many people who spend large amounts of time on the internet are quite familiar with. In fact, moviegoers who have seen The Social Network (Sorkin, 2010)—a recent tech start-up/biographical movie with a screenplay written by Aaron Sorkin based on a book by Ben Mezrich (Mezrich, 2009) about Mark Zuckerburg and the founding of the social networking website Facebook - can recall scenes in this movie in which one or more characters make reference to other characters who on multiple occasions are "plugged in" to the internet and, thus, "connected" to the internet's neural information network.

There is an especially intriguing scene in the Avatar (2009) movie in which the character Dr. Grace Augustine, an interplanetary exobiologist and cultural anthropologist (played in the movie by Sigourney Weaver), confronts the corporate administrator of the interplanetary expedition who is overseeing the human mining operations to extract the large unobtanium deposits from the Pandoran moon. Dr. Augustine has become exasperated with this corporate administrator's blatantly insensitive and callous disregard for the indigenous Na'vi and their cultural/ spiritual dedication to respecting and preserving all forms of life existing in their Pandoran natural environment. The corporate administrator, in fact, at this point in the movie's timeline has already given orders to his workers to use explosives to begin demolishing the massive trees standing on top of the substantial Pandoran underground deposits of unobtanium that the human mining corporation is bent on extracting for human benefit. These ancient, massive trees on Pandora — honeycombed with natural hollows and alcoves—are the physical and spiritual "homes" of the Na'vi Omaticaya clan, within which Omaticayan clan members and their families make their natural home dwellings. In this scene, in which the insensitive, resource-hungry perspective of the corporate mining administrator collides head-on with Dr. Augustine and her avatar team's anthropologist inclinations toward protecting the rights of interplanetary indigenous cultures, Dr. Augustine pointedly chastises the chief mining administrator and attempts to persuade him of a more collaborative solution: "I'm talking about something real, something that's measurable in the biology of the forest. What we think we know is that there is some kind of electro-chemical communication between the roots of the trees, like the synapses between neurons, and 
each tree has $10^{4}$ connections to the trees around it, and there are $10^{12}$ trees on Pandora. It's more connections than the human brain. Get it, it's a network, it's a global network, and the Na'vi can access it. They can upload and download data, memories, at sites like the one you just destroyed. The wealth of this world isn't in the ground, it's all around us. The Na'vi know that and they are fighting to defend it. If you want to share this world with them you need to 'understand them' [emphasis added]" (Avatar, 2009: scene 20). For Augustine, "understanding" the Omaticaya means fully grasping the particular way these Na'vi clansmen view and interact with their natural environment. In short, Dr. Augustine is exhorting the human mining corporation executive to recognize and respect the "Na'vi worldview" - a worldview that accords a fundamental physical and spiritual primacy to the "interconnectedness of all living things" on Pandora, which for the Na'vi includes the "spirits" of their ancestors who are linked to the Na'vi people through their environment. Most importantly, Grace Augustine is making a passionate claim that the Na'vi have discovered an invisible "resource" on their planetary moon that is even more valuable than the unobtanium deposits: the Na'vi have intuitively developed a deep understanding of and a collective ability to tap into and harness the substantial power of communal learning networks. And, intriguingly, these communal networks provide the Na'vi with multiple sociocultural opportunities for exponentially increasing their interactive knowledge sharing and collaborative learning.

The above-referenced Avatar (2009) movie scene (along with additional supporting scenes in the Avatar movie), potentially employed in conjunction with selected scenes from other recent movies dealing with "social networking" and "collaborative learning" such as The Social Network (Sorkin, 2010), can serve as excellent conceptual framing exemplars to jumpstart reflective conversations among graduate students on how school leaders can work collaboratively with fellow educators to design and implement creative, technology-integrated teaching and learning initiatives in elementary and secondary schools. Considering again the urban high school "digital technology integration" case in point presented above, the Avatar (2009) movie scene(s)—used as conceptual framing exemplars to guide graduate teaching about organizational change leadership-can provide graduate students with intriguing opportunities for gleaning new organizational change insights regarding the multiple instructional payoffs that high school students and teachers can derive through designing and implementing communal learning networks in their secondary school classrooms. For example, many innovative high school educators today are becoming increasingly involved in utilizing problem-based learning (PBL) instructional techniques in conjunction with open-collaborative peer learning models of teaching to design highly creative Global Science Education (GSE) learning projects to substantively expand and diversify their technologyintegrated teaching practices. These teacher-led GSE initiatives are emerging in response to the recent inclusion in many school district vision and mission statements of a recognition on the part of school district leaders of the need to educate students to acquire an "informed awareness" of and a sense of "communal responsibility" toward addressing the collaborative leading and learning challenges and opportunities associated with participation in a $21^{\text {st }}$ century global society. This increasing trend, engaged in by more and more education leaders, of rearticulating school district vision and mission statements to include a "global learning" dimension reflects recent calls for reinventing teacher instructional practices that are now appearing in new editions of national teaching and learning standards emerging from several US national education organizations. A prime example of these new standards is the Next Generation Science Standards (NGSS) for teaching and learning science in US elementary and secondary schools (National Academy of Sciences, 2012). Developed through a collaborative effort of the National Research Council (NRC), the National Science Teachers Association (NSTA), and the American Association for the Advancement of Science (AAAS), the Next Generation Science Standards are based on a rigorous national Framework for K-12 Science Education (National Research Council, 2011) and focus specifically on STEM-integrated science teaching and learning in elementary and secondary classrooms. Notably, the NGSS standards include strong emphases on the instructional value and importance of "breaking down classroom walls" and "expanding networked learning opportunities for students" through global, interconnected teaching and learning. School leadership graduate students seeking to apply Avatar (2009) movie scene insights supporting the instructional payoffs of incorporating communal learning networks into educators' instructional practices could leverage the NGSS emphasis on global, interconnected teaching and learning as a standards-based starting point for designing some highly creative and implementable "global-collaborative science learning" projects.

For example, large swaths of the southwestern United States and the inland land expanses of Australia share similar geographic profiles and ecosystems, with both of these continental areas having limited rainfall and ground water resources. As a result, people living in these two geographic areas share similar environmental 
challenges on how to best conserve their limited water resources and utilize their available water supplies efficiently for irrigation, livestock use, urban reservoir planning, etc. Science teachers in the Dallas/Fort Worth urban high school case example (described above) seeking to integrate NGSS standards into their classroom teaching could leverage principles of communal networked learning to identify and partner with teacher colleagues in a "sister" urban secondary school in Canberra, in southeastern Australia. Working together via internet-enabled instructional design planning (using email, instant messaging, LinkedIn, Twitter, and similar online communication and sharing tools as an integrated communal e-learning network), this collaborative teacher team could design and develop a "global-collaborative, problem-based science learning" project for their US and Australian students. Within this global science learning project students in the Dallas/Fort Worth urban high school and students in the urban high school in Canberra would create their own e-learning network community - using the same kinds of digital, internet-enabled communal networking tools leveraged by their teachers-to collaboratively brainstorm and identify a well-defined, focused learning problem of mutual interest to both student groups (such as: "how to utilize limited water resources efficiently and creatively for optimal urban vegetable gardening"). The students could then collaborate as a "global scientific research team" to investigate the problem and generate some creative water conservation and urban gardening/hydration solutions to benefit vegetable gardeners in their respective urban communities. This global team of science students could utilize a wide array of mobile technologies (computer laptops, tablets, personal cell phones, and the like) and digital audio and video production tools available at their schools to collaboratively write and produce narrated video segments documenting their "urban vegetable gardening" problem-based learning project efforts. Additionally, these global science students could even collaborate to design their own "global-collaborative science learning" website to showcase their ongoing global science project activities and to solicit comments and feedback from "global science" students in other countries. Furthermore, teachers and students could also invite interested members of their larger school communities (parents, civic leaders, and scientific professionals such as geologists, horticulturalists, urban community planners, and environmentalists) to become involved in their global science learning project activities as mentors/coaches and project evaluators who would interact with students via project website chat rooms and blogs. Intriguingly, through becoming actively involved in leveraging mobile technologies and social media to pursue their problem-based science project activities, students will begin to explore and discover new interdisciplinary "links" or "connections" between and across multiple content areas, which will add multidisciplinary depth to their learning. Indeed, the design possibilities for these kinds of "global-collaborative learning projects" are only limited by the creative imaginations of the students, teachers, and school community members involved.

The Dallas/Fort Worth-Canberra global science education project example presented above highlights multiple, noteworthy "instructional payoffs" that students and teachers can derive through actively designing globally-connected, problem-based learning projects and participating in these projects via digital (internet-enabled) communal e-learning networks. These instructional payoffs include the educational potential of mobile technology and social media learning networks for: 1) expanding opportunities for globally-connected communal sharing and learning; 2) nurturing intergenerational communication links across continents and cultures; 3) enabling networking participants to engage in real-world, collaborative problem identification and problem solving; 4) facilitating "group reciprocity" through peer coaching which can cultivate heightened collective learner enthusiasm for and interest in approaching real-world problems from multiple "vantage points"; and 5) naturally supporting, enabling, and expanding the possibilities for "multidisciplinary" inquiry and learning. Most significantly, these global-collaborative learning projects can immerse students directly (along with their teachers and interested community members) in using digital creation and communication tools to globally collaborate together on problems and issues of practical importance to their communities-enabling these students, teachers, and community members to experience for themselves the substantive teaching and learning benefits that all learners can derive through creating and participating in $21^{\text {st }}$ century digital, internet-enabled communal e-learning networks.

\section{Conclusion}

This article has presented an overview and discussion of the author's use of conceptual framing exemplars as a creative instructional tool in graduate teaching seminars to enhance school leaders' reflective thinking and applied skill development in designing and implementing meaningful learning improvement initiatives in elementary and secondary school settings. The selected organizational change leadership concepts highlighted in this 
article—namely, the leadership challenges associated with: 1) nurturing collaborative teaming mindsets among multiple school district stakeholders; 2) using conflict situations creatively as catalysts for positive organizational change; and 3) leveraging $21^{\text {st }}$ century technologies to create digital learning networks to benefit all learners-represent some of the most pressing (and vexing) organizational change and improvement challenges confronting school leaders today. Cinematic portrayals of organizational conflict, human resiliency, and creative change leadership enacted within various story settings and places as can be found in available classic films and popular movies can provide an array of intriguing and highly applicable resources that those interested in school leadership graduate training and development can employ to creatively expand and enliven the study of school organizational change leadership for today's school leaders. These cinematic resources can be used creatively as conceptual framing exemplars to focus students intently on critically examining relevant organizational change "issues" and teaching and learning improvement "challenges" of current interest to educators and community stakeholders in elementary and secondary schools and districts. Most importantly, the use of conceptual framing exemplars in graduate teaching can help "set the stage" (a la Cervantes) for enhanced leadership learning and development-through providing leadership students with a rich multimedia-supported and multiple disciplineinformed instructional platform for generating new leadership insights and creative action strategies that school leaders can use in practical ways to help realize meaningful teaching and learning improvements in their own school settings.

\section{References}

Cameron, J. (2009). Avatar [Motion Picture]. United States: Twentieth Century Fox Film Corporation and Dune Entertainment, LLC.

Cervantes Saavedra, M. de (1605). Don Quixote de La Mancha. English Translation (1882) by Peter Anthony Motteux, with Notes by John G. Lockhart. London: William Clowes and Sons, Limited.

Chardère, B. (1995). Les images des Lumière. Paris: Gallimard.

Coppola, F. F. (1972). The Godfather [Motion Picture]. Hollywood, CA: Paramount Pictures.

Goodwin, D. K. (2005). Team of Rivals: The Political Genius of Abraham Lincoln. New York: Simon \& Schuster.

Kushner, T. (2012). Lincoln: The Screenplay. New York: Theatre Communications Group.

Man of La Mancha (1972). Film Adaptation. United Artists Corporation. Warner Home Video Release (1991). Culver City, CA: MGM/UA Home Video, Inc.

Mezrich, B. (2009). The Accidental Billionaires: The Founding of Facebook. New York: Doubleday.

Munro, J. H. (2008). Organizational Leadership: Roundtable Viewpoints. Dubuque, IA: McGraw-Hill Contemporary Learning Series.

National Academy of Sciences (2012). Next Generation Science Standards: Executive Summary. Washington DC: National Academies Press. http://www.nextgenscience.org/

National Research Council (2011). A Framework for K-12 Science Education: Practices, Cross-Cutting Concepts, and Core Ideas. Washington DC: National Academies Press. http://www.nationalacademies.org/publications/index.html

Owens, R. G. (2004). Organizational Behavior in Education: Adaptive Leadership and School Reform. New York: Pearson Education.

Puzo, M. (1969). The Godfather. New York: New American Library/Penguin Group USA.

Sorkin, A. (2010). The Social Network [Motion Picture]. Culver City, CA: Columbia Pictures Industries.

Spielberg, S. (2012). Lincoln [Motion Picture]. United States: DreamWorks II Distribution Co., LLC and Twentieth Century Fox Film Corporation.

Wilhelm, M., \& Mathison, D. (2009). James Cameron’s Avatar: An Activist Survival Guide. New York: HarperCollins Publishers. 
Scientific Research Publishing (SCIRP) is one of the largest Open Access journal publishers. It is currently publishing more than 200 open access, online, peer-reviewed journals covering a wide range of academic disciplines. SCIRP serves the worldwide academic communities and contributes to the progress and application of science with its publication.

Other selected journals from SCIRP are listed as below. Submit your manuscript to us via either submit@scirp.org or Online Submission Portal.
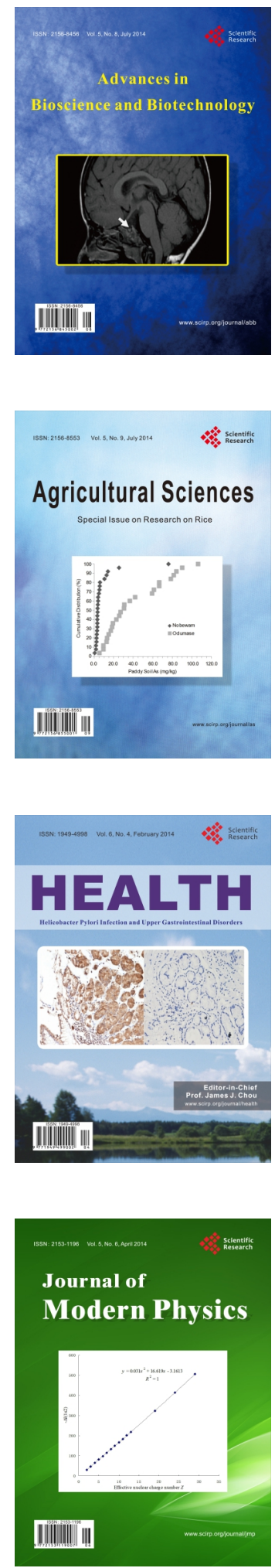
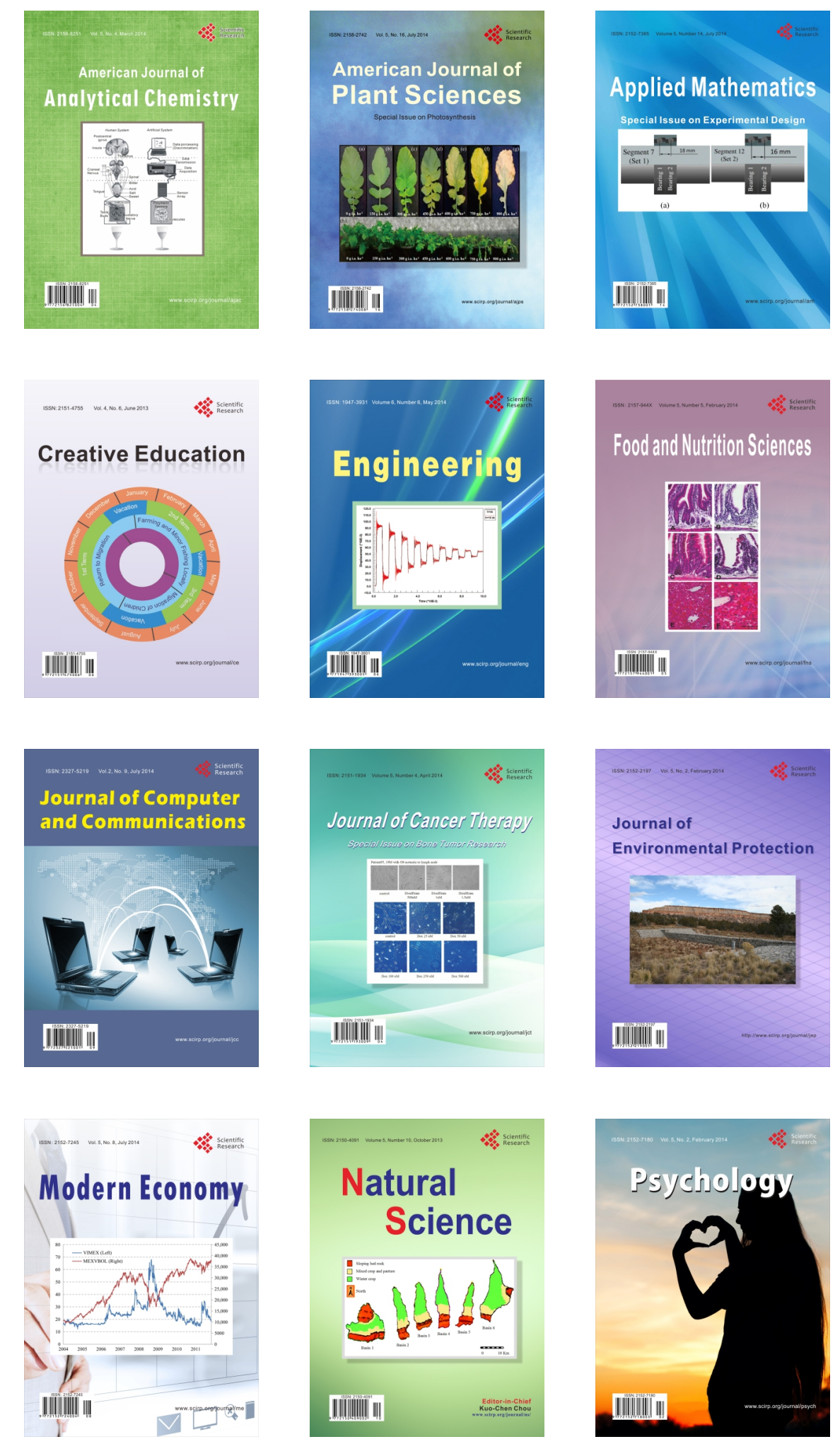